fixation and dehydration of tissues at low temperatures in vacuo, and refrigerating units. These are very useful additions to the constant-temperature rooms recently installed for dealing with problems demanding special temperatures.

The library has been successful in filling the gaps caused by the War. It now contains some $\mathbf{4 5 , 0 0 0}$ volumes, including two hundred and fifty periodicals.

The boats used for collecting have been repaired and the regular supply of living material is assured.

The names of the following visitors show that the institute has regained its position as an international centre : J. and A. Runnström, with G. Lundblad as assistant (Wenner-Grens Institut, Stockholm); A. Bohus Jensen (Carlsberg Laboratory, Copenhagen); L. J. Mullins (Berkeley, Califormia), all working upon the physiology and biochemistry of fertilization, partly with radioactive isotopes; S. Hörstadius (Uppsala), physiology of development in sea-urchin eggs; J. Z. Young and B. B. Boycott (University College, London), the behaviour of Octopus and effect of operation on the central nervous system; Miss E. M. Brown (Plymouth), parasitic Protozoa; Miss Helen Brown (Cambridge), protein skeletons in invertebrates; $H$. Nüiesch (Basel), Echinodermata.

Intending visitors are asked to write to the Director setting out their requirements, since many of these are now likely to be met from apparatus in possession of the laboratory. Visitors should also communicate with him concerning apparatus of their own which they wish to bring, as the Director can arrange for exemption from duty at the local Customs. He can also give full information concerning arrangements for lodging; and of that characteristic feature of the institute, the 'mensa', which offers the two main meals of the day to visitors at reasonable prices.

\section{ELECTRICAL STIMULATION OF THE NEUROHYPOPHYSIS IN THE CONSCIOUS ANIMAL}

$\mathrm{G}$ W. HARRIS (Phil. Trans, Roy. Soc. Lond., $\mathrm{B}, 232,385 ; 1947)$ has devised an ingenious and successful method for electrical stimulation of the hypothalamus or neurohypophysis in the fully conscious rabbit.

A small secondary coil connected to two electrodes was placed between the scalp and the dorsal surface of the skull. The stimulating electrode, a fine insulated platinum wire, was passed through a plug accurately fitting a trephine hole of the skull down through the brain in the middle line until its bared tip lay in the hypothalamus or in the neurohypophysis itself. The indifferent electrode lay between the scalp and skull. The coil and electrodes were fixed in the animal at a preliminary operation, and after recovery the animal showed no ill-effects from the presence of the stimulating unit, indeed it appeared to be quite unconscious of it. Animals have lived up to three years with the unit in place.

A primary coil fed from the A.c. mains, when brought near the animal, energized the embedded secondary coil and so electrical stimulation of any desired intensity could be applied by remote control. Positive results, indicating activity of the neurohypophysis, were obtained when the electrode was in the supraoptico-hypophyseal tract or in the neurohypo. physis itself. No results were obtained when the electrode tip was more than half a millimetre away from these structures. Stimulation for a period of 5-10 min. was shown to cause inhibition of a water diuresis and an increase of urinary chloride. In female rabbits, during natural or artificially induced œstrus, stimulation brought about a marked increase of uterine contraction, but little or no effect was observed in the anœstrous or pseudopregnant uterus. This is in conformity with the ordinary results of injecting posterior-pituitary extracts.

These results demonstrate clearly that the neurohypophysis in the normal animal can liberate a hormone or hormones which have antidiuretic and oxytocic activity. Particular interest attaches to the oxytocic effect ; for, although the oxytocic action of posterior-pituitary extract has long been known as a pharmacological phenomenon, the demonstration that a natural hormone having oxytocic action is ever secreted by the neurohypophysis during life has hitherto been lacking.

\section{FORTHCOMING EVENTS}

(Meeting marked with an asterisk * is open to the public)

\section{Tuesday, May II}

ROYAI SOCIETY OF ARTS, DOMINIONS AND COLONIES SECTION (at John Adam Street, Adelphi, London, W.C.2), at 2.30 p.m.-Mr. C. B. Symes: "Control of Insect-borne Diseases in the Coloniessome Recent Progress and Future Prospects".

ROYAl ANThropological INSTitute (at the Royal Society, Burl ington House, Piccadilly, London, W.1), at 5 p.m-Prof. Raymond Firth : "Religious Belief and Personal Adjustment" (Henry Myers Lecture).

ZOOLOGICAL SOCIETy OF LONDON (at the Zoological Gardens,

ZOolOGICAL SoOIETy OF LONDON (at the Zoological Ga
Regent's Park, London, N.W.8), at 5 p.m. - Scientifle Papers.

INSTITUTION OF CIVIL ENGINEERS (at Great George Street, London, S.W.1), at 5.30 p.m.-Mr. T. H. Seaton: "Coast Erosion and Sea Defence, with Special Reference to Problems on the East Coast of England associated with the London and North Eastern Railway" Mr. C. R. Irving: "The Effect of Winds and Tides on Sea Coast Defence Works in North Wales".

INSTITUTION OF ELECTRICAL ENGINEERS RADIO SECTION (at Savoy Place, Victoria Embankment, London, W.C.2) at 5.30 p.m $\longrightarrow \mathrm{Mr}$. R. Ruddlesden, Mr. E. Forster and Mr. Z. Jelonek: "Carrier Frequency Shift Telegraphy": Mr. J A. Smale: "Some Developments in Com munication Point-to-Point Radiotelegrap".

SOCIETY OF PUBLIC ANALYSTS aND OTHER ANALYTICAL CHEMISTS, BrolOGICAL METHODS GROUP (at the Chemical Society, Burlington House, Piccadilly, London, W.1), at 6.30 p.m.-Dr. A. A. Miles : "Bouse, Piccadilly, Lon

SOCIETY OF INSTRUMENT TECHNOLOGY, NORTH-WEST SECTION (at the College of Technology, Manchester), at 7.15 p.m.-Annual Genera Meeting; Mr. C. F. Budenberg: "Pressure Gauges with Specia Reference to their Selection, Installation and Maintenance".

\section{Wednesday, May 12}

Geological Sochety (at Burlington House, Piccadilly, London W.1), at 5 p.m. -Dr. Frederick Murray Trotter: "Devolatilization of Coal Seams in South Wales".

Institute of PETRoLedM (at Manson House, 26 Portland Place London, W.1), at 5.30 p.m.-Films illustrating various phases of the Petroleum Industry.

INSTITUTION OF ELECTRICAL ENGINEERS, TRANSMISSION SHCTION (at Savoy Place, Victoria Embankment, London, W.C.2), at 5.30 p.m. -Mr. B. Calvert: "Transformer Economic Efficiency".

Wednesday, May 12-Thursday, May 13

British Ceramto SocIETy, REpraOTORY MATERIALS SECTION (at the Institute of Mining and Mechanical Engineers, Neville Hall, Westgate Road, Newcastle-upon-Tyne)-Spring Meeting.

\section{Thursday, May 13}

Chadwiok PUBlic Lecture (at University College, Nottingham), at 4 p.m.- Sir Arthur MacNalty: "Advances in Preventive Medicine during the War of 1939-1945".

LINNEAN SOCIETy of LoNDON (at Burlington House, Piccadilly, London, W.1), at 4.30 p.m.-Discussion on "The Orientation of Birds on Migratory and Homing Flights" (to be opened by Dr. D. H. Wilkinson and Dr. W. H. Thorpe)

INBTITUTION OF ELFOTRICAL ENGINEERS (at Savoy Place, Victoria

Embankment, London, W.C.2), at 5.30 p.m.-Annual Generai Meeting. BRITISH INSTITUTION OF RADIO ENGINEERS, LONDON SECTION (at the London School of Hygiene and Tropical Medicine, Keppel Street, London W.C.1), at 6 p.m.-Mr. I. A. Harris: "The Calculation of Electrode Temperatures in the Radio Valve". 